\title{
CORRESPONDENCE
}

\section{The Phuket Group of peninsular Thailand}

SIR,-The paper by Mr A. H. G. Mitchell (Mitchell, Young \& Jantaranipa, 1970) describing this thick Palaeozoic succession of terrigenous clastic rocks fills another gap in what is geologically perhaps the least documented part of South-east Asia. BP genlogists carried out a reconnaissance survey over the whole of southern Thailand in 1968 and 1969 and in addition to covering the area mapped by Mitchell $e t$ al. we were able to examine the lateral equivalents of the Phuket Group. Two features of this unit which seem outstanding are its great thickness and the presence of pebbly mudstone intervals.

The origin of this pebbly (and cobbly) mudstone could perhaps have been discussed in greater detail by Mitchell et al. After all, if the same rock of the same age were to have been found in India or Australia it would certainly have been compared with the Gondwana boulder beds of those countries, for which many workers have accepted a glacial origin. I agree with Mitchell et al. that the pebbly mudstone of the Phuket Group is a geosynclinal deposit and in reaching this conclusion $I$ was influenced by its strong resemblance to the tilloids of the West Congo geosyncline, still thought by some workers to be glacial tillites but re-interpreted by Schermerhorn \& Stanton (1963) as mud-flow deposits. It is interesting to note also that boulder beds in India have recently been shown to be of non-glacial origin (Biswas, 1970).

Leaving aside the question of how the rocks were deposited, this stratigraphic resemblance between Thailand and India is one of several pieces of evidence that Southeast Asia did indeed once form part of Gondwanaland, a possibility which, again, is too lightly dismissed by Mitchell et al. There is, for example, evidence in Malaysia, peninsular Thailand and the Cambodian border area of Thailand that during the Early Palaeozoic, Permian and Triassic the source area was west of present-day Thailand and at each of these times there was an eugeosynclinal belt lying to the east of a more stable region in the west.

In that part of peninsular Thailand to the south and east of the prominent bend which is crossed by the Khlong Marui Fault (Garson \& Mitchell, 1970) a different succession outcrops from that described by Mitchell et al. Cambrian deltaic deposits are overlain by the Ordovician to Silurian Thung Song Limestone. Then, unconformably overlying this limestone and underlying the Permian Rat Buri Limestone, is a group between $1000 \mathrm{~m}$ and $2000 \mathrm{~m}$ thick which is the lateral equivalent of part, if not all, of the Phuket Group. Pebbly mudstone is developed only locally and the more typical lithology is mudstone with abundant well-rounded quartz sand grains, passing in the extreme south-east to non-sandy shale. The sandy mudstone is very like the matrix of the pebbly mudstone of the Phuket Group and it could be described as pebbly mudstone without pebbles. Unlike Mitchell et al. I suggest that the source of the Phuket Group did lie to the west. The south-eastward transition (from the thick Phuket Group with pronounced tilloid intervals, to a similar though thinner succession, mostly lacking large clasts, and finally to a thin succession of fissile non-sandy shale) fits well with the interpretation of a wedge of clastic sediments building out to the east of a continental land-mass. It is noteworthy also that toward the south-east, beyond the area in which Mitchell et al. worked, there is no deltaic facies underlying the Permian Rat Buri Limestone as there is in the type area of the Phuket Group; this is the reverse of the scheme suggested by Mitchell et al.

The dissimilarity of the Indian diamonds and those in Thailand which are believed to have eroded out of the Phuket Group is surely a very small stumbling-block to accepting an old connection between the two countries. Could not their different geological histories account for such differences as do exist? If not from India, one is forced to postulate a source of Thailand's detrital diamonds somewhere to the east in a region where no primary diamonds are known until Australia is reached.

Finally, it is hard to see why Mitchell et al. propose that the Phuket Group includes strata of Ordovician and even Cambrian age when there is strong evidence that it is 
entirely post-Silurian. As mentioned above, the Palaeozoic succession of the southeastern part of peninsular Thailand comprises Lower Palaeozoic rocks of quite different facies from the Phuket Group: deltaic deposits (Jones, 1968) overlain by the Thung Song Limestone. And yet the succeeding group of Middle Devonian (Kobayashi \& Hamada, 1968) to Permo-Carboniferous age has lithological similarities with the Phuket Group and is most simply viewed as being its lateral equivalent. Furthermore, the numerous limestone clasts in the Phuket Group tilloids are lithologically like the Ordovician to Silurian Thung Song Limestone and if they were derived from the latter (or its equivalent to the west?) the Phuket Group must be younger.

Acknowledgement. I am indebted to The British Petroleum Company Limited for permission to publish this note.

\section{References}

Biswas, B. 1970. Rising continents, deepening ocean basins and their changing configuration. Basudeb Biswas, Calcutta.

Garson, M. S. \& Mitchell, A. H. G. 1970. Transform faulting in the Thai Peninsula. Nature, Lond. 22, 45-7.

Jones, C. R. 1968. Lower Paleozoic rocks of the Malay Peninsula. Bull. Am. Ass. Petrol. Geol. 52, 1259-78.

Kobayashi, T. \& Hamada, T. 1968. A Devonian phacopid recently discovered by Mr Charan Poothai in peninsular Thailand. In Kobayashi, T. and Toriyama, R. (Eds.): Geology and palaeontology of Southeast Asia, Vol. 4, 22-8. University of Tokyo Press, Tokyo.

Mitchell, A. H. G., Young, B. \& Jantaranipa, W. 1970. The Phuket Group, Peninsular Thailand: a Palaeozoic ?geosynclinal deposit. Geol. Mag. 107, 411-28.

Schermerhorn, L. J. G. \& Stanton, W. I. 1963. Tilloids in the West Congo geosyncline. Q. Il geol. Soc. Lond. 119, 201-41.

BP Petroleum Development Ltd

Box 2814

Singapore

1st April 1971

\section{The Phuket Group of Peninsular Thailand}

SIR,-We are grateful to Mr Ridd for showing that to the south and east of the Klong Marui fault the Phuket Group lies unconformably on the Thung Song Limestone. Ridd's results indicate that here, at least, the base of the Phuket Group is no older than late Silurian.

Within Peninsular Thailand conclusive evidence for the direction of provenance of the Phuket Group is so far lacking. Although sedimentary facies and vertical facies relationships can be recognised, lack of detailed stratigraphic control in a folded and faulted succession obscures lateral facies relationships; comparison of lithologies in widely separated exposures of limited area is of doubtful value as a basis for paleogeographic reconstructions. The predominantly argillaceous succession described by Ridd from the area to the south-east of the Klong Marui Fault may be a distal deep water deposit; alternatively it could be interpreted as having accumulated in a restricted environment near an easterly source area, while thicker flysch-type sediments were deposited in deeper water further west.

The paired eugeosynclinal and miogeosynclinal belts of the Malay Peninsula (Jones, 1968) have a northerly trend and lie well to the south-east of Peninsular Thailand. The belts are of Lower Palaeozoic age and hence older than much and possibly all of the Phuket Group. Ridd suggested that limestone pebbles in the Phuket Group were derived 